\title{
From Creating Spaces to Evoking Images: $4+1$ Hamlets in Slovak Theatre
}

Jana Wild

\begin{abstract}
This paper reflects upon staging Hamlet in Slovakia from 1950 to 2004. The five selected productions brought seemingly different designs of the theatrical space. And yet in four of them, there were many similarities in terms of mimetic understanding of the space. There was only one, nearly unnoticed production in the Rusyn language (2004) building a completely different space: based upon sophisticated visual principles derived from Spanish and Dutch Golden Age paintings, inviting the audience to read Hamlet as a contemplation on a highly performative society.
\end{abstract}

\section{Keywords}

Shakesperare, Slovak theatre, scenography, history 
The focus of this paper is on staging and designing Hamlet in Slovak theatre across more than half a century. Researching and close reading of the stage designs of five particular productions from 1950 to 2004 will trace the changing political climate in the society, too. For not only was the Slovak theatre dependent on state policy, it has been haunted by Jan Kott's spirit, applying - sometimes strictly and sometimes rather less so - his ideas of 'Hamlet our contemporary'. This journey through time aims to show that in terms of understanding space and visual design, there was a persistent stereotype which was only breached by a seemingly marginal production in 2004 .

In a period of more than a half century - from 1950 to 2004 - in Slovak professional theatre, Hamlet has been staged about ten or eleven times. Relevant to public consciousness and/or to national theatre history ${ }^{1}$ would be five of them. Of these five, four achieved considerable public acclaim: three staged in the capital city Bratislava (1950, 1964 and 1974), and one close to it in Nitra (2001); the geographically furthest away production in Prešov, Eastern Slovakia (2004) is hardly known at all - and yet, it deserves much of attention, even though post factum.

Thus, the first four parts of the essay will consider the four productions of 1950, 1964, 1974 and 2001 to show their paradigmatic status as predecessors of the fifth - the radical breakout ventured in 2004 .

\section{Hamlet - topical and political}

The socio-political context of staging the first discussed productions up to 2001 was a substantial part of their appeal and has influenced the scenography, too. In more than fifty years from 1950 onwards, staging Hamlet, Shakespeare's major tragedy, was understood as a political statement in its own right. Dealing with and mirroring the political situation was deeply inscribed into staging Hamlet in the Cold War era in Czechoslovakia: the early 1950s as the era of growing post-war Stalinism; the mid 1960s as the era of de-Stalinisation, of new hope and of relaxing ideological pressure, even of 'looking back in anger', as the major Hamlet production of 1964 did; the mid 1970s as the era of what the communist regime called 'normalisation', but what in reality meant a return to totalitarianism - these particular eras produced their own politicised and highly topical Hamlets. Even a decade after the fall of the iron curtain, in the era of growing neo-liberalism, a Hamlet of 2001 in Nitra still stuck to the Kottian paradigm. In all these times, even if the outer appearance of the productions might have looked different, the notion of the space - whether full or bare - followed the same pattern of understanding and interpreting the play.

Hamlets in Slovak culture have had about the same paradigmatic meaning as the critic Bartoshevich noticed on Russian reception of the play: 'The changing interpretations of Shakespeare's tragedy by Russian critics, writers, painters, composers, theatre

1 At least in my consideration, based upon detailed research which has led to two publications on Hamlet in Slovakia, see (BŽOCHOVÁ-WILD 1998; BŽOCHOVÁ-WILD 2007). 
artists, etc., mirror with extraordinary precision the evolution of Russian society and culture. To conceive the substance of any period of Russian history in the 19th and 20th centuries you should just find out how people of that time interpreted Hamlet: then you'll touch the nerve of the moment' (BARTOSHEVICH 2017).

Studying the visual and textual materials from the four productions considered in this essay, one can read clearly how the politics and ideology informed their interpretation and their stage design. The 'performative turn' made by the fifth and last discussed production in Prešov in 2004, offered a completely new vision of space and also provided a new way of reading the play.

\section{Stalinism: 1950.}

\section{Justifying Tragedy in an Era of Optimism}

The first Hamlet in the Cold War era paid tribute to Stalinism and schematism. It was an era promoting communist optimism, promoting the crowd against individualism, promoting a bombastic visual style - typical of totalitarian regimes' aesthetics: supressing anything individual, intimate and subtle. The fronts (the oppressors vs. the oppressed) had to be clearly defined, no ambiguities nor scepticism were allowed. ${ }^{2}$

Even staging tragedy, which opposed the ideologically promoted overall cheerful optimism, needed courage (if not special permission) and a justification. It is hardly surprising that the co-director and protagonist of Hamlet anno 1950, Jozef Budský, declared defensively in advance: 'In our great age, the so-called Hamletian problem is over and solved already' (BUDSKÝ 1950).

The ideological pattern imposed from the Soviet 'Big Brother' was the same elsewhere in the Eastern Bloc, as A. Shurbanov and B. Sokolova argued most convincingly: 'Hamlet's theoretical transformation [...] has been completed: the allegedly melancholy Prince has been reformed and fully drawn into the ongoing class struggle for mankind's glorious future. [...] Hamlet has become the heroic harbinger of the future; consequently, he is destined to remain all alone in an absolutely hostile world controlled by the reactionary forces of feudalism and capitalism...' (SHURBANOV and SOKOLOVA 2001: 182). What was meant to appeal was his romantic 'self-sacrifice in the name of the people' (SHURBANOV and SOKOLOVA 2001: 181).

Thus, what justified staging Hamlet in the Stalinist era was his 'humanism' (BUDSKÝ 1950; SHURBANOV and SOKOLOVA 2001: 152, 180, 182; SENELICK 2006: 141, 151) and the Prince's 'active' struggle for social justice within despicable feudal circumstances. In those years, no resemblance to contemporary society was desirable - and it was particularly the visual aspects of performance that pinned up the remote historicity of the story.

2 Czechoslovakia was strongly controlled by the USSR since the communists took power in February 1948. The culture was dominated by Stalinist ideology, imposed by Andrei Zhdanov and his followers, castigating 'any hint of pessimism, introspection, or disillusion' (SENELICK 2006: 146). 
At this time, the principal stage designer in Bratislava was Ladislav Vychodil who later became a leading personality of modern Slovak scenography, well known also abroad. Based on photographs and drawings, one can easily make out that Vychodil submitted himself to a schematic descriptionism: the stage was dominated by huge operatic architecture - heavy and dark, full of massive blocks, pushing down any human dimension. As if any breath for imagination, any subtle individual feeling was swallowed up. The fortress-like solidity and monumentality conveys a sense of awe and intimidation, diminishing the individual. To supress any suspicion of individualism, there was a scene inserted into the production with revolting crowds breaking onto the stage - as was common elsewhere in the Eastern bloc (SHURBANOV and SOKOLOVA 2001: 102), including the subsequent famous Okhlopkov production of 1954.

\section{On Making Hamlet anno 1950}

Rather than the scenography itself, the most revealing aspect of the 1950 design is the designer's verbal explanation published in the theatre bill. Even if trying to justify and explain his naturalistic 'operatic' solution, he rather makes us believe that what he did is not exactly what he would have liked himself - as if leaving a message in a bottle. The scenographer Vychodil's report on making the stage for Hamlet 1950 unveils the process of his ideas, concerns, decisions and - of his mental self-censorship. His words and a couple of drafts attached to the text demonstrate that initially, his ideas of how to create the space of Hamlet were quite different - and rejected (possibly by himself?).

His first draft was a simple sketch conveying 'a cathedral-like monumentality' similar to 'Gorgon Greig [sic]' (VYCHODIL 1950). However, this 'would unrightly [sic] introduce the categories of fate, God and metaphysics in general into the play' (VYCHODIL 1950) - categories strictly banned from communist ideology and therefore unacceptable. Dismissing this first idea as 'unrighty', Vychodil would look for another way to convey the - Marxist - idea of 'a strong oppressive kingdom' (VYCHODIL 1950). This, says the scenographer, might be achieved easily by an 'expressionistic solution: illogical architectural elements. The space may evoke a cellar, dramatically constructed materials convey a stringent impression' (VYCHODIL 1950). Yet, as he continues, '[t]his solution relies on visual phantasy of the spectator, not on his logical thinking' (VYCHODIL 1950). Precisely this - the element of fantasy - made it 'decisively erroneous' (VYCHODIL 1950) again.

The only way out of this dilemma was to follow the stereotypes of Socialist Realism: 'The decoration should express the world of the king, e.g. the world of intrigues, cabals and murders. [...] as if overburdened with a massive ashlar of medieval darkness which stifles the whole epoch' (VYCHODIL 1950). This was to be achieved by using descriptive elements: 'Finally, there remained a platform as ground for the throne with lions' heads on both sides. Symbol of oppression and the despotism of the king' (VYCHODIL 1950). In accordance with the demands of schematism, the designer decided '[ $\mathrm{n}]$ ot to 
rely on a visually educated spectator, but rather on a spectator who does not know anything about how the artistic -isms work, nor on deformation; but on a spectator who apprehends everything purely rationally: 'this is a door to enter the room, the room is small or big etc.' This might be called a 'scenography of meanings' (VYCHODIL 1950).

Thus, the 'politically correct' idea prevailed and Vychodil set out 'to build a historically accurate, clearly defined space to make the spectator continually believe that the story happened at the end of the Gothic age' (VYCHODIL 1950). The stage design followed the Stalinist argument that Hamlet's tragedy could happen in the Middle Ages only, with its massive social oppression, as opposed to the contemporary communism free of existential conflicts.

It is very illuminating to read Vychodil's text now and to follow the whole process of supressing creativity on behalf of a problematic tendentious ideal, renouncing any imagination; this is an authentic report on self-censorship and on victory of the ideological super-ego.

But, in a way, this text and its accompanying drawings display also a sort of childish naivety of that age, too. Artists - the directors, the translators and the scenographer alike are driven to schematism; but, at the same time, they are given the possibility to explain their process of decision and even to mark other ideas, provided they dismiss them. This very aspect of early 1950s Stalinism is remarkable, too. (Later on, in the 1960 s and 1970s, as I will show, the scenographers were allowed to free the stage from heavy material and naturalism and to address the imagination; yet concerning verbal expression, the 1970s were most stringent, allowing no discussion nor clash of arguments at all.)

The ideological colonialism dominating the bill is pinned down by an interview with the Soviet theatre director Popov who claims Shakespeare for the Soviet Union (and its vassals) only: 'Thus we can say that today, Shakespeare's home is the Soviet Union. He responds to us with his emotions and ideas which his progeny - the English bourgeois is scared of' (POPOV 1950). ${ }^{3}$

\section{A Dictum of the Era?}

Paradoxically, Vychodil's massive abrasive fortress-like walls resemble the walls in the 'English bourgeois' Lawrence Olivier's filmed Hamlet (1947) which was shown and well-known in post-war Czechoslovakia - even though Olivier's visual style followed a different aim and weaved rather a different atmosphere. However, the tendency to monumentalise the space was obviously a dictum of the post-war era; only a couple of years later, the Soviet stage designer Vadim Ryndin built a heavy operatic space, too,

3 By the way, exactly these words are reported to be said on the 300-year celebrations of Shakespeare in Moscow in 1964, i. e. almost 15 years later, as Irena R. Makaryk has demonstrated in her paper '1964: Shakespeare in the USSR' held within the panel 'Shakespearean Festivals and Anniversaries in Cold War Europe 1947-1988' at the international conference Shakespeare. 450 in Paris, 21-27 April 2014. 
for Okhlopkov's Hamlet in Mayakovski Theatre (1954). I will speak about the visual design of that Russian production when dealing with the Slovak Hamlet of 1974.

\section{Antistalinism: 1964.}

The second important Slovak Hamlet of the Cold War era was staged in 1964, when the long process of the de-Stalinisation of society had just been accomplished. ${ }^{4}$ Yet, the wounds of the previous Stalinist era with its many victims were still blazing. Thus, Hamlet was still felt as a 'drama of political crime'. No doubt, there was a direct connection to Polish Hamlets of the late 1950s after Stalin's death, as Jan Kott had written on them. ${ }^{5}$ During this political 'thaw', Hamlet became extremely appealing in the whole Eastern Bloc: there sparked a true "Hamlet fever. [...] Hamlet now became a "titan of conscience" and a brother-in-arms in the battle against residual Stalinism' (MAKARYK 2006: 117).

The National Theatre production in Bratislava was conceived as a clear political statement and as an explicit outburst against the Stalinism of the previous years. The protagonist Karol Machata, a charismatic actor and a beloved of the contemporary audience, was standing in the proscenium as a young man devastated by the moral corruption of the generation of his parents, in fortissimo 'shouting accusations into the audience' (JABORNÍK 1996). There, among the spectators on the gallery, the Ghost was walking, locating the story of the clash of generations directly into the contemporary audience.

Whereas Vychodil's space of 1950 was realistic by necessity, Čestmír Pechr endeavoured his stage to be '[n]on-illusive, variable, enabling quick changes and creating the needed dramatic spaces' (PECHR 1964). He refrained from any realistic elements referring to any specific time, and was about 'to build a severe, simple scene, to strip it of any typical theatre props, non-decorative' (PECHR 1964). In sharp contrast to the Hamlet of 1950, Pechr left the stage bare, and structured it horizontally by low grey platforms and a corridor to suggest a tomb. A 'tomb for living characters', as he explained (PECHR 1964). To the sober plain horizontals of the stage elements, the actors were juxtaposed as the only verticals. The main accent was on verbal acting - the director Tibor Rakovský was a convinced Brechtian. His design with the grey platforms may resemble the socialist urban spaces of that time - all those dull grey blocks where the eyes have nothing to hang on to, where there is nothing to lean on. Reading the motionless

4 Stalin died in 1953. It took until February 1956 for Nikita Khrushchev to denigrate his policies at the 20th Party Congress. Thus, the era of de-Stalinisation gradually opened. In the vassal state Czechoslovakia, the political process of 'thaw' was similar. 1956: the personality cult of Stalin was denounced; 1960-1962: political prisoners were released via amnesties; 1963: the politically disgraced were officially rehabilitated and restored to public life.

$5 \quad$ In the same year as the production opened, an extract of Jan Kott's book Szkicie o Szekspirze [Sketches on Shakespeare] was published in Slovak (Slovenské divadlo, 1964) and the whole book in Czech (Shakespearovské crrty, 1964). 
photographs now, the visual design conveys a sense of loneliness of human existence. The overall feeling to be evoked by the stage image was of a tomb: cold, emotionally negligent, inhuman. Hamlet was the only one to revolt against this deadness: 'loudly, aggressive' (DEDINSKÝ 1964), 'furiously' (SEVER 1964) 'an angry young man, without decorum' (ČAVOJSKÝ 1964).

Nevertheless, in the rapidly changing and politically thawing times of the mid 1960s, the angry Hamlet's shouting has been slightly out of date. There were other media starting to question the recent past more directly, so there was no need to use Shakespeare as a foil and to express the mind by reading between the lines anymore.

\section{3. 'Normalisation': 1974.}

The third relevant Hamlet of the Cold War was directed by Miloš Pietor ten years later, in an entirely different situation. The 1970 s were the era of the communist 'Normalization', following the Soviet military invasion of Czechoslovakia (1968), when the unquestionable communist rule was restored and any openness or reformist ideas 'leading to chaos' were denounced. Censorship over the media was re-established, borders to Western countries were closed. However, in comparison with early 1950s Stalinism based upon hunting 'state enemies', upon overt political repressions and violence, the 1970s' official ideology of 'normalisation' rejected open political violence and promoted instead a restoration of order, 'working in peace' and 'peaceful social coexistence' (KOLÁǨ and PULLMANN 2016: 62). This 'creeping normalisation' operated rather with invisible violence and intimidations towards selected 'maladaptive' social groups, depriving them of their voices and their rights.

This Hamlet, though, was probably one of the most topical Slovak Hamlet productions ever. ${ }^{6}$ Its opening - when the funeral turns to a wedding ceremony - referred clearly to the 'normalised' socio-political reality: to the advancement of dubious people, to the pragmatic turncoats and to overall equivocalness. The 'double life' and invisible deprivation of those years could not be demonstrated better. Furthermore, there were other factors clearly referring to the reality of that time, e. g. the cast.

Whereas Claudius, Polonius, Gertrude, Fortinbras, Osric etc. were played by older members of the theatre company and put rather in rough and grossly barbaric costumes (there was no Ghost), the actors who played the young generation (Hamlet, Horatio, Ophelia, Laertes, even the gravediggers-clowns) were former members of an alternative company known for its political opposition which had been dissolved in 1971. They were the electrifying, vividly young people, full of energy and inner flame, sensitive and self-reflexive - and bitterly sarcastic as a result of their recent human experience of restraint. The costumes of the young aristocratic people made of smooth shining bright fabric (dress, shirts) and tight leather (trousers) suggested a romantic life style and accented strong physicality. Thus, there was a clear line dividing the two

6 A part of the following text on the 1974 Hamlet production was published in (WILD 2017b). 
groups of actors, emphasised by their outfits (designed by Stanislava Vaníčková). This line, recognised by most of the contemporary local audience, pointed to the clash between the hangers-on and the rebel-victims after the 1968 events in the country.

The physicality of the young generation - strong, vibrant and fragile at the same time - is worth mentioning: there was nothing like the idealism of shouting verbal arguments, as the previous Hamlet of 1964 did; here, there were beautiful young people emotionally tormented up to the point of physical rudeness. The overall harshness, be it in words, ${ }^{7}$ manners or pointed physical action, conveyed a strong feeling of dismay among the spectators, too.

The main element of the bare stage (with only two chairs) were huge bars hanging at the backdrop, sharply lit from above when in action, threatening all the time to fall down. Interestingly enough, none of the contemporary records mention them, neither verbally nor visually. (All the black-and-white archive photographs depict only the actors, as if avoiding to show the bars. The reviewers did not mention them either.). Yet fortunately for us, four decades later there appeared many additional colour slides (recorded then by the scenographer Otto Šujan himself), conveying the suggestive atmosphere governing the whole production. Indeed, Hamlet unfolding in a prison.

The bars, especially when pulled down, marked the line between here and there: 'there' would rather mean 'beyond', for on the other side is but death. 'Denmark is a prison', obviously, this is what we read in Shakespeare. Yet in the prison on the stage, nobody would see any remote 'Denmark'. People in Czechoslovakia were similarly trapped behind the iron curtain in those years. This powerful performance went under the skin and touched the social and political misery of the country under 'normalisation'.

I have mentioned Okhlopkov's and Ryndin's Russian Hamlet of 1954 before. Though using huge bars, ${ }^{8}$ suggesting a prison, too, Ryndin's scenography was rather excessively overabundant ${ }^{9}$ with its massive presence of heavy metal structures and gates. However, the trend two decades later, in the 1970s, as shown by Efros and Liubimov, went rather towards 'identifying a central scenic emblem that could encapsulate the contemporary meaning' (SENELICK 2006: 139). Exactly this was the case of the Pietor/Šujan production in Bratislava, too. No doubt, Ryndin's understanding of the space seems closer to the overstuffed fortress-like stage of Vychodil anno 1950 than to the threatening bare prison of Šujan of the 1970s, even though both had used the bars to suggest a prison.

7 This Hamlet was the first stage production of a new, rather crude translation made by the high communist apparatchik Jozef Kot, who became a prolific and monopolist translator of Shakespeare into Slovak in the 1970 s and 1980 s.

8 I am grateful to Viviana Iacob (Romania) who has brought Okhlopkov's production with the bars to my attention.

9 SENELICK, Laurence. 'Thus conscience doth make cowards of us all. New documentation on the Okhlopkov Hamlet' (MAKARYK and PRICE, 2006: 136-156). Among other evidence, Senelick discusses into detail the visual changes enforced after the general rehearsal in 1954. 


\section{Towards a Visual Sobriety}

To conclude from these three historically strongly embedded Hamlets, we may assess that the strategies of visual design have refined over the years, in favour of 'metaphorical' and allegorical scenography. From the 1960s onwards, there was a sort of freedom of visual speech, and a desire to shake off the decorative exuberance, a tendency towards sophisticated visual sobriety. Clearing and emptying of the Hamletian stage in the 1960 s and 1970 s lead to giving priority to the actors. Whereas loud verbal acting into the audience (1964) did not work well, the emphasised physical acting and the frailty/bulkiness of the actors in 1974 apparently took effect.

Nevertheless, the designers - still conforming with the idea of Shakespeare's doublespeak - were trying to find a condensed allegory of the overall existential feeling. For Shakespeare has definitely worked as a foil for contemporary concerns. The designers, be it Vychodil, Pechr or Šujan, all have adopted an Aesopian language of fable, too.

\section{Neoliberalism: 2001.}

The fall of the iron curtain, in 1989, with the inauguration of democracy definitely meant a historical landmark and a socio-political revolution. And again, the response concerning Shakespeare was similar throughout the whole of the former Eastern Bloc's theatres: the new liberty of 'anything goes' has provoked 'iconoclastic impulse[s]' (SHURBANOV and SOKOLOVA 2001: 258), be it in Bulgaria, Poland or Hungary. ${ }^{10}$ Many young directors felt an urge to stage Hamlet as a man of a new world where there are no stable values.

At the turn of the millennium, in 2001, the most popular Hamlet production in Slovakia was staged in 'Quentin Tarantino style' (ULMANOVÁ 2001) by a young Hungarian team (Robert Alföldi as director, Kentaur, i. e. László Erkel, as stage designer) in Nitra. There was deafening loudness, naturalistic violence, explicit sex and incest on the stage. Hamlet (Marek Majeský): a hooligan, son from a wealthy family, smashing the questionable authority of his father. And - as the witnesses of then Bulgarian Shakespeares ascertained, too: there was hardly any sense of moral differentiation (SHURBANOV and SOKOLOVA 2001: 259). Eventually, Hamlet in Nitra came across as a purely visual PR idol, as a fancy figure from an advertising spot.

Significantly enough, the insistent signs of the new era were appearing on the surface, too. The stage stunned with aggressive visual bombast: overfilled (overkilled) with trendy stuff such as computers, mobile phones, dark sunglasses, inline-skates, fast food, Walkmans, bodyguards, wall graffiti, pornographic video, revolvers, a plush teddy bear. The setting for Hamlet of the era of flourishing neo-liberalism was - what else? - a business company. Not the 'state of Denmark' but 'Danmark company'.

10 See e. g. (SHURBANOV and SOKOLOVA 2001: 249-266 or some essays in BŽOCHOVÁ-WILD 2014). 
Part of the communication went through the internet and a computer game. The director's and dramaturg's claim to catch 'global problems and feelings' (ALFÖLDI and SPRUŠANSKÝ 2001) displayed itself in a visual opulence, stating that the core of Shakespeare's story is truly 'simple' (ALFÖLDI and SPRUŠANSKÝ 2001). This seemingly 'new' Hamlet production eventually operated with rather obsolete mimetic tools: creating a space recognisable for the audience, multiplying pictures from their own reality (WILD 2001: 11).

\section{Conclusion of Hamlets 1-4 (1950-2001)}

As these four major productions have demonstrated, the visual solutions for these Hamlets rested upon a mimetic approach with stable meanings. The designs of Elsinor, referring to recognizable topoi from contemporary reality, represented a fortress (1950), a tomb (1964), a prison (1974) and a business company (2001).

All the designers, be they under or beyond political pressure, considered the space as more or less definite and allegorical; they created a theatre of 'grand metaphor'. Additionally, all the Hamlets were handsome men, slender, romantic figures fashioned as young rebels to be identified with.

\section{A 'performative turn': 2004. ${ }^{11}$}

A radical shift in staging Hamlet in Slovakia happened 2004, yet was almost completely unnoticed..$^{12}$ In the Eastern Slovakian theatre Divadlo Alexandra Duchnoviča (DAD) in Prešov, the First Quarto version $(\mathrm{Q} 1)$ of the play was translated into Rusyn by dramaturg Vasil' Turok, radically cut and staged by Rastislav Ballek and designed by Vladimír Čáp. DAD, the professional theatre company of the Ruthenian/Rusyn ethnic minority, has been one of the most innovative and experimental of the Slovak state-subsidised companies and a playground of experimentation for many visiting directors.

Shakespeare in Rusyn, the neglected sped up Q1 text and the whole approach was something that has not been seen in the Slovak staging history of Shakespeare before and made the production highly remarkable.

Also Eugen Libezňuk, physically rather a robust man in his early 40 s, cast as Hamlet was a noticeable step away from the tradition. Libezňuk was not the kind of iconic handsome person the audience would immediately identify with; and his Hamlet was rather de-centred and de-heroised. Instead of the usual inward insight into the protagonist, the production focused on playing with the geometrical juxtapositions and

11 Some parts of the text commenting on the DAD production are taken from my essay (WILD 2017a).

12 The production was shown only four times, due to sudden passing away of Vasil Turok. Turok was the spiritus movens of the company - for this production, he translated Hamlet into Ruthenian and played the Ghost, too. There were no critical reviews published. Fortunately, there is a reliable DVD recording available in the Theatre Institute Bratislava, offering a possibility to examine and 'excavate' it post factum. 
framings of the characters on the stage and turned the attention to shifting unstable interrelations.

The production - albeit fast on the level of speech - unfolds as a series of pictures built upon permanent dissociation and destabilisation of the focus and on subtle playing with visual effects - techniques partly borrowed, I argue, from Spanish and Dutch Golden Age paintings (cf. El Greco, Velázquez, Rembrandt, Vermeer) or others (H. Bosch).

The space of Vladimír Čáp is a small black box with vertical blocks on both sides, mostly lit from the sides. The production used only movable platforms (coffins, as it would become apparent later) and a movable wheeled frame. These elements enabled the division of the space in different horizontal bands and depths. The space itself seems to be dissolved: one cannot tell the inside from the outside, the public space from the private one, you even cannot say who is supposed to be there and who not. The scenes are built in layers and some intersect in time.

The blurred high sky on the horizon, with heavy clouds shining in tones of light orange, yellow and dark grey, seem threatening. The Ghost appears in the vanishing point of the stage picture as a monument cut in stone, brightly lit from aside and rather blurred. Speaking to him in complete darkness, with a shimmering torch in his hand, Hamlet is facing the audience, as it is with most of the dialogues.

The situations are staged as tableaux vivants in areas of light and half tones. The dominant colours are black and dark shades of brown; only men's shirts are white, Gertrude's long dress is purple. In particular moments, some of the objects or sections are lit in jarring orange and yellow.

The viewer's visual focusing is permanently challenged by shifting of the movable or imagined frames and platforms, by re-arranging the spatial juxtapositions of the characters and thus creating different stage pictures with changing foreground, background, depths and compositional diagonals. As we may suppose, the idea governing these suggestive pictures was to stage the story as an image of a performative society with unstable meanings: the production put on stage characters who play roles, who either stage, arrange, govern this playing or who watch the others playing. Playing roles seems to be the universal model of behaviour. Who is the player, who the viewer/voyeur? You never know who is actually playing for whom; the positions mix up constantly.

The situations, and so the assumed spaces alike, often overlap and present a sort of Foucauldian 'heterotopia', a site in terms of a grid 'capable of juxtaposing in a single real place several spaces, several sites that are in themselves incompatible' (FOUCAULT 1984). The simultaneity of the imagined spaces and even of some of the successive events (news on Ophelia's drowning and her funeral; the duel and nailing the coffins for the dead characters) suggests collapse of time.

Hamlet's presence is as if he would be walking in a museum. Playing roles also means being always framed, placed as objects on pedestals, juxtaposed, grouped and gazed upon. The audience is invited to perceive the story as if standing in front of a succession of layered pictures with shifting and often uncertain focal points. The characters look rather out of the frame or frontally to the audience. Though 
their counterparts are placed within the picture itself, it is the outside viewer who is spoken to, who is meant to be involved. As no gaze is stable, the very reality of what we are looking at is doubted, and hence the nature of the social world is questioned, too.

This production, confronting the plain realism of speech with the unsettling character of images, was a highly remarkable staging of Hamlet. Its aesthetics and visual design evading mimetic models seems ground-breaking. After decades of staging Hamlet in coded moral Aesopian language, this production left many of the clichés behind and took a step towards a new understanding of the text and performance and towards conceptual theatre.

\section{Postscript}

This line of new approaches towards Shakespeare was followed by other alternative productions, e. g. by a Hamlet project on the edge of visual installation and video art: the multi-media performance Hamlet Machine (2007) by the independent performer Sláva Daubnerová. ${ }^{13}$

\section{Bibliography}

ALFÖLDI, Robert. 2001. Svetozár 2001. Drzosí, túžba, mystika... interviewed by SPRUŠANSKÝ. Shakespeare, William: Hamlet. Nitra: DAB 2001, s. p. [theatre bill], 2001.

BARTOSHEVICH, Alexey V. 2017. The Fortunes of Russian Hamlet. Russkij Šekspir [online], 2017. Available online at: http://rus-shake.ru/criticism/Bartoshevich/Russian_Hamlet

BŽOCHOVÁ-WILD, Jana. 1998. Hamlet: dobrodružstvo textu [Hamlet: The Adventure of the Text]. Levice: LCA, 1998.

BŽOCHOVÁ-WILD, Jana. 2007. Malé dejiny Hamleta [The Little History of Hamlet]. Bratislava: SND a Slovart, 2007.

BŽOCHOVÁ-WILD, Jana (ed.). 2014. "In double trust". Shakespeare in Central Europe. Bratislava: VŠMU, 2014.

ČAVOJSKÝ, Ladislav. 1964. Past na svědomí. Rudé právo (15. 5. 1964). Available online at: http:// archiv.ucl.cas.cz/index.php?path=RudePravo/1964/5/15/4.png

DEDINSKÝ, Móric M[ittelman]. 1964. O Shakespearovi, dnešku a Hamletovi [About Shakespeare: Today and Hamlet]. Kultúrny život 23 (6. 6. 1964).

FOUCAULT, Michel. 1984. Of Other Spaces: Utopias and Heterotopias. Architecture/Mouvement/ Continuité (October 1984): 46-49. Available online at: http://web.mit.edu/allanmc/www/ foucault1.pdf.

JABORNÍK, Ján. 1996. A personal conversation, August 2nd 1996 in Bratislava.

13 Her detailed account of interpreting and staging the post-dramatic text of Heiner Müller is published in (WILD 2018). 
KERSHAW, Baz. 2001. Dramas of the Performative Society: Theatre at the End of its Tether. New Theatre Quarterly 17 (2001): 203-211. doi:10.1017/S0266464X0001472X.

KOLÁ̌̆, Pavel and Michal PULLMANN. 2016. Co byla normalizace? Studie o pozdním socialismu [What was Normalisation? A Study of Late Socialism]. Prague: Nakladatelství Lidové noviny a Ústav pro studium totalitních režimů, 2016.

MAKARYK, Irena R. and Joseph. G. PRICE (eds.). 2006. Shakespeare in the Worlds of Communism and Socialism. Toronto/Buffalo/London: University of Toronto Press Incorporated, 2006.

PECHR, Čestmír. 1964. Slovenský Hamlet [Slovak Hamlet]. Slovenské divadlo 12 (1964): 4: 521.

PERVIĆ, Muharem. 2002. Chamlet bez granica [Hamlet without Borders]. Politika (2. 10. 2002) (Belgrade). Quoted according to Divadelné správy DÚ Bratislava 3: 10 (December 2002): 18.

POPOV, A. D. 1950. A. D. Popov o shakespearovskom repertoári v sovietskom divadle [A. D. Popov on the Shakespearean Repertoire in the Soviet theatre]. Shakespeare, William: Hamlet. Bratislava: SND, 1950, s. p. [theatre bill].

SEVER, Peter [Jozef Bobok]. 1964. Hamlet, ktorý sa nepýta. Smena (17. 5. 1964).

SHURBANOV, Alexander and Boika, SOKOLOVA. 2001. Painting Shakespeare Red. An East-European Appropriation. Newark: University of Delaware Press. London: Associated University Presses, 2001.

ULMANOVÁ, Martina. 2001. Shakespeare na spôsob Tarantina [Shakespeare à la Tarantino]. Mosty 10: 27 (3. 7. 2001): 12.

VYCHODIL, Ladislav. 1950. Problémy výtvarníka pri inscenácii Hamleta [The Designer's Problems in Creating Hamlet]. Shakespeare, William: Hamlet. Bratislava: SND 1950, s. p. [theatre bill].

WILD, Jana. 1998 - BŽOCHOVÁ-WILD, Jana. 1998. Hamlet: dobrodružstvo textu [Hamlet: The Adventure of the Text]. Levice: LCA, 1998.

WILD, Jana. 2001. Jednoducho Hamlet [Simply Hamlet]. Divadlo v medzičase VI (2001): 1: 10-11.

WILD, Jana. 2007 - BŽOCHOVÁ-WILD, Jana. 2007. Malé dejiny Hamleta [A Short Cultural History of Hamlet]. Bratislava: SND a Slovart, 2007.

WILD, Jana. 2017a. 'The Art of Performance': Staging Hamlet in Rusyn Language. In Courtney Krystyna Kujawinska and Grzegorz Zinkiewicz (eds.). Shakespeare and his Infinite Variety. Lódź: Lodź University Press, 2017: 145-150.

WILD, Jana B. 2017b. Hidden (Pilgr)images. Two Slovak Shakespeares of the 1970s. In Ioan Cristescu and George Volceanov (eds.). Shakespeare in Romania, Shakespeare in the World. Bucuresti: Editura Muzeul Literaturii Romane, 2017: 95-100.

WILD, Jana B. (ed.). 2018. Shakespeare medzi Vel'kým treskom a South Parkom [Shakespeare from the Big Bang to South Park]. Bratislava: Európa, 2018. 


\section{Theatrography}

\section{SHAKESPEARE, William. Hamlet}

SND Bratislava. Premiere: 1 April 1950. Translated by Zora Jesenská. Directed by Ivan Lichard, Tibor Rakovský, Jozef Budský. Music by Ján Cikker. Choreography by Stanislav Remar. Costumes and stage design by Ladislav Vychodil. Cast: A. Bagar, J. Budský, K. Zachar, J. Pántik, V. Záborský, K. Machata, H. Meličková, M. Královičová, O. Budská etc.

\section{SHAKESPEARE, William. Hamlet}

SND Bratislava. Premiere: 2 May 1964. Translated by Zora Jesenská and Ján Rozner. Directed by Tibor Rakovský. Music: Jaroslav Dlouhý. Choreography: Milan Herényi. Costumes: Stanislava Vaníčková. Stage design: Čestmír Pechr. Cast: L. Chudík, K. Machata, V. Záborský, E. Kristínová, O. Sýkorová, G. Valach, A. Mrvečka, Z. Grúberová, E. Vášáryová, F. Zvarík J. Adamovič etc.

\section{SHAKESPEARE, William. Hamlet}

NS Bratislava. Premiere: 15 February 1974. Translated by Jozef Kot. Directed by Miloš Pietor. Music: Milan Novák. Choreography: Aladár Kogler. Costumes: Stanislava Vaníčková. Stage design: Otto Šujan. Cast: V. Müller, M. Huba, D. Blaškovič, M. Kňažko, J. Kukura, M. Labuda, P. Debnár, E. Rysová, M. Vášáryová, I. Čillík etc.

\section{SHAKESPEARE, William. Hamlet}

DAB Nitra. Premiere: 9 June 2001. Translated by Jozef Kot. Text adapted, music selected, directed by Robert Alföldi as guest. Dramaturgy: Svetozár Sprušanský. Choreography: Attila Király. Costumes: Andrea Bartha. Stage: Kentaur. Cast: M. Majeský, M. Ochránek, D. Kuffelová, I. Šebesta, A. Gáborová, E. Petovský, M. Zelmanová, M. Labuda ml., K. Kolembusová, J. Hrčka, P. Gecík, S. Pitoňák, O. Hudecová, A. Rimko etc.

\section{SHAKESPEARE, William. Gamlet}

DAD Prešov. Premiere: 20 March 2004. Translated into Rusyn by Vasil Turok. Directed by Rastislav Ballek as guest. Dramaturgy: Vasil Turok. Music by Norbert Bodnár as guest. Costumes and stage design: Vladimír Čáp as guest. Cast: E. Libezňuk, V. Rusiňák, S. Škovranová, J. Tkáč, J. Pantlikáš, Z. Halamová, S. Hudák, V. Turok, I. Stropkovský, A. Kučerenko, M. Marko, L. Mindoš etc. 


\section{prof. PhDr. Jana Wild PhD.}

Theatre Faculty, Academy of Performing Arts Bratislava, Slovakia wild@vsmu.sk

Jana Wild is professor at the Academy of Performing Arts Bratislava, Slovakia. Her writings on Shakespeare include monographs in the Slovak language: Hamlet: the Adventure of a Text (1998), The Enchanted Island? Shakespeare's 'The Tempest' Otherwise (2003), A short cultural history of Hamlet (2007), Shakespeare. Zooming (2017). She edited and translated a section on Shakespeare 'From women's reading to feminisms' for the feminist revue Aspekt (Aspekt, Nr. 2, 2001). Recently she edited three international collections of essays 'In double trust'. Shakespeare in Central Europe (2014, in English), Mirrors of/for the Times. Shakespeare in Central European Theatre (2015) and Shakespeare in Between (2018, in English). In Bratislava, she has organised two international conferences on Shakespeare $(2013,2016)$ and established the platform Shakespeare-Slovakia.info. Since 2017, she is board member of ESRA (the European Shakespeare Research Association). 